\title{
High-Tech Companies are the Driver of Regional Economic Development
}

\author{
B. A. Begalov ${ }^{1}$, A. D. Zhukovsky $2,3,{ }^{*}$ \\ ${ }^{1}$ Chairman of the State Committee of the Republic of Uzbekistan on Statistics, Tashkent, Republic of Uzbekistan \\ ${ }^{2}$ Financial University under the Government of the Russian Federation, Moscow, Russia \\ ${ }^{3}$ Ural State University of Economics, Yekaterinburg, Russia \\ ${ }^{*}$ Corresponding author. Email: jukoffsky@gmail.com
}

\begin{abstract}
This article is devoted to the development of high-tech companies in the modern economic market. The authors present the definition of a high-tech company, it is shown that with the development of the digital economy, high-tech companies are increasingly effectively carrying out their activities in the economic market and have a multi-sided positive impact on the development of regions. In addition, the article shows that high-tech companies, through their own scientific developments, the introduction of advanced solutions in the activities of industries and spheres of the economy of the regions, contribute to the development of the business environment, training of the personnel of economic facilities, the quality of life of the population of the regions. The article notes that high-tech companies use a full range of modern innovations in their activities: technical ones. technological, marketing, organizational, process, etc. As the main characteristics of high-tech companies, the article highlights such as the use of progressive achievements of science and technology in the main areas of the company's work, the presence of trade secrets, the production of goods and services, information security, profitability, instantaneous pace of change, constant integration with scientific institutions, mobility and uniqueness of specialists.
\end{abstract}

Keywords: high-tech companies, regional economy, digital technologies, innovative solutions, development, quality of life of the population, progress, scientific research, highly qualified personnel, efficiency.

\section{INTRODUCTION}

In the modern period, high-tech companies have developed in the economic literature and in the economic market.

A high-tech company means a whole material complex, the main capital of which is highly qualified personnel, extensive introduction of innovations in the production of products, widespread use of IT technologies, digitalization of all management processes.

This concept in the Russian Federation was initially reflected in such legislative acts as the Decree of the Government of the Russian Federation No. 832 of July 24, 1998 "On the Concept of Innovation Policy of the Russian Federation for 1998-2000", in the "Strategy of the Russian Federation in the field of science and innovation development for the period up to $2010 "$ ".

As practice shows, the main characteristic of hightech companies is the introduction of various kinds of innovations into production: technological, organizational, marketing, process, product, etc. This complex allows us to note that the competitiveness of high-tech companies is ensured through the use of scientific developments and discoveries, the results of their own research on advanced areas of activity or the study of the experience of foreign and domestic scientists and practitioners.

In addition, world experience shows that high-tech companies invest in science and conduct independent scientific research, conduct testing and introduce them into the production process, which has a great impact on the development of the country's economy as a whole, and also promotes close cooperation with science, government and business.

\section{MATERIALS AND METHODS}

In the course of writing the article, methods of system analysis, grouping, synthesis, analytical data processing, 
methods of working with the Internet computer network were used.

\section{RESULTS AND DISCUSSION}

The functioning and development of high-tech companies in the modern economic market is the subject of research of a number of scientific works of domestic and foreign scientists. In particular, such authors as Abramov A. E., Radygin A.D., Chernova M. I. [1], Dzhukha V. M., Dzyubenko I. B., Barinova V. A., Bortnik I. M., Zemtsov S. P., Infimovskaya S. Yu., Sorokina A.V. [2], Belousov D. R., Abramova E. A., Apokin A. Yu., Evseeva M. V., Mikhailenko K. V., Penukhina E. A., Frolov A. S. [3], Golovanova S. V., Leonova L. A., Zemtsov S. P., Chernov A.V. [4], Dmitriev M. E., Romashina A. A., Chistyakov P. A. [5], Vlasova N. Yu., Adamaitis S. A., Barinova V. A., Kidyaeva V. M., Kotsyubinsky V. A., Semenova R. I., Fedotov I. V., Tsareva Yu. V. [6], Gavrilova S. V. [7], Acs Z. J., Parsons W., Tracy S. [8], Brown R., Mawson S. [9] and others.

Publications by such authors as Simachev Yu. V., Radygin A.D., Ivanov D. S., Johansson A., Guillemet I., Murtin F., Korotkov M. Yu., Kuznetsov B. V., Kuzyk M. G., Misyura A.V., show that additional support is provided by the state to large holdings and high-tech companies [10].

Scientists of the Ural State University of Economics make a great contribution to the study of the problem of the influence of high-tech companies on the economy of the region. These include the works of Animits, Vlasova N. Yu., Silin Ya. P., Dvoryadkina E. B., etc.

In the modern period, the presence of high-tech companies in the national economy allows us to note the following positive features:

- high-tech companies carry out effective innovative activities, create new innovative goods and services, use all types of resources as efficiently as possible, especially in the regions;

- develop and implement new technological solutions in production, develop innovative services, which contributes to the creation of new jobs in the regions and increase labor productivity;

- create products with high added value that are effectively sold on the domestic and foreign markets and contribute to the growth of competition;

- contribute to the development of related sectors of the economy.

The research of modern scientists and practitioners shows that in the modern period there are more than 2000 high-tech companies operating on the Russian economic market .

For example, according to the calculations of analysts of the SibAkadem Soft Association, presented at the SIIS - 2019 forum - there are currently 646 system-forming companies on the Russian economic market, including 21 high - tech companies.

And the results of a study by the analytical publication IDC (International Data Corporation) show that the services of high-tech companies in the field of IT technologies in the modern period are distributed across several sectors of the domestic IT market.

The first place according to the results of this study belongs to services in the field of IT outsourcing. And as follows from the above-mentioned studies, the primacy here belongs to the" Laboratory of New Information Technologies " - "Lanit", which provides a full range of services for the provision of subscription services for servers and computers, as well as performs complex technical support and audit.

In the modern period, a significant part of companies is engaged in the production of IT equipment. In this aspect, specialists named such companies as "Aquarius", "KraftWay", "Yadro", "Rikor", "Eltex", etc. as leaders. The main activity of the above-mentioned companies is the production of laptops, servers, various components for various types of computers and complex industries $[11,12]$.

In the field of software development on the market of the Russian Federation, joint-stock company 1C. Practice shows that the software products of this company are effectively used both in the economic market of the Russian Federation and exported to other countries. Enterprise management systems (ERP, Big DATA, CRM, industry information systems), unique algorithms implemented in artificial intelligence systems. PaaS/Saas cloud services have become widespread in the activities of many economic entities in various countries of the near and far abroad. [13-15].

According to the conducted research, Kaspersky Lab has been identified as the leader in the field of information security in the Russian market. This hightech company provides services in the field of cybersecurity, biometric digitization, access control, etc.

In the field of applied segments (banking sector, defense industry, healthcare, agricultural sector, etc.), the Center for Financial Technologies, which implements advanced technologies and services the information systems of the largest banks, has the palm of superiority.

In the same area, experts note such companies as Sbertech, which organizes the technical support of Sberbank, Rostelecom, Ascon, which is an integrator in the field of automation of design and production activities, etc. The distinctive features of high-tech companies in the economic market are:

- high development potential that contributes to the long-term viability of a high-tech company in the economic market, the impact on expanding the need for new innovative solutions and entering new markets; 
Table 1. The main functions of high-tech companies in the modern economic market.

\begin{tabular}{|c|l|l|}
\hline $\begin{array}{c}\text { № } \\
\Pi / \Pi\end{array}$ & \multicolumn{1}{|c|}{ The main functions of high-tech companies } & \multicolumn{1}{|c|}{ Areas of application } \\
\hline 1. & New scientific developments and discoveries & $\begin{array}{l}\text { High-tech industries and } \\
\text { sectors of the economy }\end{array}$ \\
\hline 2. & Development of basic innovations or modification of existing innovative solutions & $\begin{array}{l}\text { Branches and spheres of the } \\
\text { economy }\end{array}$ \\
\hline 3. & $\begin{array}{l}\text { Creation of basic and additional innovations for various industries and spheres of the } \\
\text { economy }\end{array}$ & $\begin{array}{l}\text { High-tech industries and } \\
\text { sectors of the economy }\end{array}$ \\
\hline 4. & Implementation of innovative products, processes and services & $\begin{array}{l}\text { Various industries and } \\
\text { spheres of the economy }\end{array}$ \\
\hline 5. & $\begin{array}{l}\text { Introduction of innovations and various technological innovations related to the } \\
\text { restructuring of individual elements of the existing production system }\end{array}$ & $\begin{array}{l}\text { Industrial enterprises and } \\
\text { organizations of the economy }\end{array}$ \\
\hline 6. & $\begin{array}{l}\text { Adaptation of innovations in individual parts of the production process without } \\
\text { significantly changing the functioning of the system as a whole. }\end{array}$ & $\begin{array}{l}\text { Various enterprises and } \\
\text { organizations of the economy }\end{array}$ \\
\hline 7. & $\begin{array}{l}\text { Creation of new generations of equipment and technological solutions } \\
\text { and enterprises and } \\
\text { organizations of the economy }\end{array}$ \\
\hline 8. & $\begin{array}{l}\text { Development and implementation of new types of production systems (products, } \\
\text { services and technologies) with qualitative changes to the original concept, but } \\
\text { retaining the basic functional principle }\end{array}$ & $\begin{array}{l}\text { Industrial enterprises and } \\
\text { organizations of the economy }\end{array}$ \\
\hline 9. & $\begin{array}{l}\text { Development of new generations of technological solutions, products and services } \\
\text { without changing their basic structural components and structures }\end{array}$ & $\begin{array}{l}\text { Industrial enterprises and } \\
\text { organizations of the economy }\end{array}$ \\
\hline 10. & $\begin{array}{l}\text { Developing innovations for new markets and innovations that create new areas of } \\
\text { application in old markets }\end{array}$ & $\begin{array}{l}\text { Various industries and } \\
\text { spheres of the economy }\end{array}$ \\
\hline
\end{tabular}

Source: compiled by the authors based on the study of special literature

- a developed information base for making competent management decisions (scientific developments, patents, inventions, licenses, new technologies, the experience of leading enterprises in the economic market, etc.);

- a multi-variant, interactive, experimental, more optimal approach to making management and production decisions;

- an innovative, flexible control algorithm based on the methods of economic and mathematical modeling;

— high commitment to strategic management;

- continuous development, training, self-education of employees of a high-tech company, etc.

Thus, it can be noted that the high-tech nature of the company is determined by the orientation of the development strategy on innovative components. Moreover, the innovative activity of high-tech companies covers all the key business processes of the company.

Practice shows that, based on innovative technological and managerial solutions, high-tech companies produce new products and services of the highest quality.

In the course of this study, it was revealed that hightech companies can perform many functions in the modern economic market (Table 1).

The data in Table 1 show that high-tech companies are based on intellectual property, develop, improve or introduce innovative products, services, technological processes that carry out independent technology transfer.
According to research, currently high-tech companies have spread all over the world. Figure 1 shows a diagram compiled by the author based on the opinions of scientists about the percentage of high-tech companies in the global space.

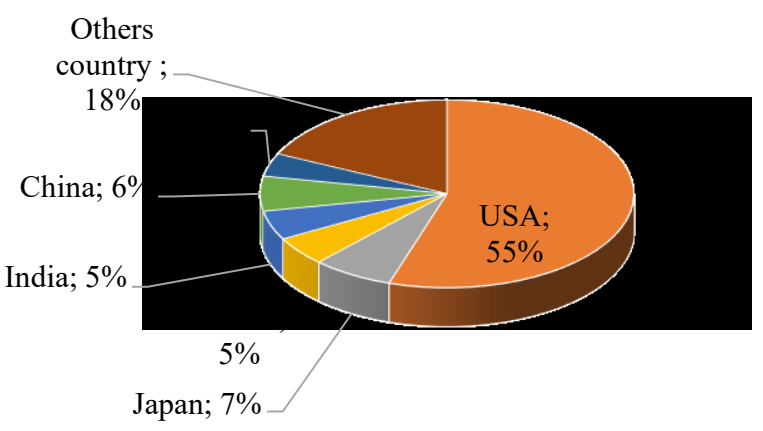

Figure 1 The share of high-tech companies in various countries of the world in 2020.

Source: Compiled by the authors on the basis of data from the Internet computer network https://institutiones.com/strategies/2667-analizosnovnyx-osobennostei.html

The analysis of the market of high-tech companies has shown that the main criteria for them are:

- the level of knowledge intensity;

- science output;

— high-tech index and innovation index 
— focus on the commercialization of scientific activities.

Modern scientists refer to the category of high-tech products products, the indicator of the knowledge intensity of which reaches at least $3.5 \%$ during production. The analysis of the conducted research shows that various international centers, in addition to calculating special indices and coefficients, use the level of commercialization of the achieved results of the company's functioning in the economic market to assess the development of technologies. In addition, practice shows that all the indicators that are currently developed are not static. With the development of technologies, the methods of their assessment and use for the effective development of industries and spheres of national economies of various regions on a global scale are also being improved.

\section{CONCLUSION}

The analysis carried out in this study shows that hightech companies in the modern period have a great influence on the development of the economy. In particular, high-tech companies in the regions of the Russian Federation can provide the following advantages:

- contribute to the creation of an innovative ecosystem for the organization and conduct of business;

- ensure the interconnection of science, business and urban infrastructure;

- contribute to the development of the production of innovative goods and services;

- serve as a link between large corporations, industrial enterprises,scientific and educational organizations, business representatives and special services for the development of urban infrastructure.

In addition, high-tech companies help attract investment to the regions of the country, develop new forms of interaction with large corporations, train personnel, conduct industry expertise, provide opportunities for concluding various transactions between enterprises and organizations in the system of smart contracts through the use of digital technologies, etc.

In the Russian Federation, a rating of high-tech companies is determined annually, which allows determining their development in the economic market. In the segment of the industry structure, the largest growth was observed among information technology companies, as well as industrial equipment and mechanical engineering - they accounted for $29 \%$ and $23 \%$ of the total number of companies participating in the rating, respectively. Statistics show that more than $40 \%$ of companies are located in Russia. The leaders are such cities as Kazan, Novosibirsk, Perm, Tomsk and Kaluga.

In addition, the analysis shows that each high-tech company that has entered the high rungs of the rating on average spends $17 \%$ of its revenue on innovations, and $\mathrm{R}$ $\&$ D expenses account for $14 \%$ of the annual turnover. At the same time, in the segment of medium and small companies, compared to 2018, there is an increase in $\mathrm{R}$ $\&$ D expenses. For the latter, the growth was $20 \%$, which indicates that the technology business has become more actively invested in innovations in order to improve product quality. At the same time, the average share of such expenses for large businesses has decreased, which indicates the completion of the cycle of formation of $\mathrm{R} \&$ $\mathrm{D}$ projects in a number of large companies. Thus, hightech companies are conduits in the economic market.

\section{REFERENCES}

[1] A.E. Abramov, A.D. Radygin, M.I. Chernova, Companies with state participation in the Russian market: ownership structure and role in the economy. Economic issues 12 (2016) pp. 61-87.

[2] V.A. Barinova, I.M. Bortnik, S.P. Zemtsov, Infimovskaya, A.V. Sorokina, Analysis of the factors of competitiveness of domestic high-tech companies. Innovations 3(197) (2015) pp. 25-31.

[3] D.R. Belousov, E.A. Abramova, A.Yu. Apokin, K.V. Mikhailenko, E.A. Penukhina, A.S. Frolov, The future of Russia: macroeconomic scenarios in a global context. Foresight 7(2) (2013) pp. 6-25.

[4] S.P. Zemtsov, A.V. Chernov, Basic factors in the development of high-tech companies. NEA Journal 1(41) (2019) pp. 68-99.

[5] M.E. Dmitriev, A.A. Romashina, P.A. Chistyakov, The role of spatial policy in accelerating economic growth. Social sciences and modernity 5 (2018) pp. 31-47.

[6] S.P. Zemtsov, S.A. Adamaytis, V.A. Barinova, V.M. Kidyaeva, V.A. Kotsyubinsky, R.I. Semenova, I.V. Fedotov, Yu.V. Tsareva. RANEPA, AIRR, National report "High-tech business in the regions of Russia" 2 (2019).

[7] S.V. Gavrilova, Conceptual foundations for defining the high-tech sector of the economy and the functioning of high-tech companies. Economics, Statistics and Informatics 2 (2015). https://statecon.rea.ru/jour/article/viewFile/383/365.

[8] Z.J. Acs, W. Parsons, S. Tracy, High-Impact Firms: Gazelles Revisited, Corporate Research Board. LLC Washington, DC 20037 for under Contract No. SBAHQ-06-Q-0014 2017. 
[9] R. Brown, S. Mawson, Targeted Support for High Growth Firms: Theoretical Constraints, Unintended Consequences and Future Policy Challenges. University of St Andrews, Working Papers in Responsible Banking \& Finance 15-006 (2015).

[10] S.P. Zemtsov, A.F. Maskaev, Growth Factors of Fast-Growing Companies in Russia: Experience of Multilevel Modeling, In: XVIII April International Scientific Conference on Economic and Social Development, NRU HSE, 2017, pp. 11-14.

[11] D.S. Medovnikov, T.K. Oganesyan, S.D. Rozmirovich, Champion Candidates: Medium FastGrowing Companies and Their Support Programs. Economic issues 9 (2016) pp. 50-66.

[12] Yu.V. Simachev, A.D. Radygin, D.S. Ivanov, M.Yu. Korotkov, B.V. Kuznetsov, M.G. Kuzyk. State anticrisis support for large and systemically important companies: directions, features and lessons of Russian practice 2016.

[13] N. Alexandrov, Man in the digital age. Expert 29(1038) (2017) pp. 26-27.

[14] N. Blayman, Dividends of the digital age. http://www.rbcplus.ru/news/59ef050d7a8aa91b526 6834d.

[15] E.B. Rogatnykh, Influence of digitalization on the development of the modern world economy. Economy and management: problems, solutions 11(5) 2017 pp. 64-70. 